\title{
LOVE IN OLD AGE
}

The previous chapters have examined personal experiences of later life in two distinct yet related fields - the elder's daily health care and his public role. In both areas, the focus was on the aging body and on different forms of self-government that shaped the expression of individual identity and permeated political thinking. Yet to what extent do we believe that we are old? How do we know that we are old? As long as the subjective feeling of youth remains alive, the "objective" evidence of age seems fallacious. "The tragedy of old age is not that one is old, but that one is young," Oscar Wilde ruefully noted. We are always the same age "inside," although a wrinkled face and an aged body legitimate some social behaviors, while excluding others. As Simone de Beauvoir wrote, "Within me it is the Other-that is the person I am for the outsider-who is old, and that Other is myself." Without the tension between these different perceptions, it is difficult to understand how we come to realize that we are growing old, for it is in relation to broader social norms of aging that we can make sense of the effects of the passing of time on our body and mind.

Renaissance self-portraits of old men in love offer a fruitful way to examine the cultural implications of this question. At stake is nothing less than the relevance of the traditional division of the life cycle into ages. ${ }^{2}$ In spite of their endless variations, literary representations of aged lovers revolve around a remarkably stable set of stereotypes. For centuries, Western philosophers, writers, and moralists have stressed the weaknesses, moral and physical, to which the ages of life are prone when it comes to experiencing love. On the one hand, they have scorned youth's concupiscence and uncontrollable passion; on the other hand, they have mocked the lustful old man and the aged misanthrope. Others have argued that as the years go by, a young man's attraction to love's sensual pleasures is balanced by emotional growth that culminates in the wisdom traditionally granted to

1 Simone de Beauvoir, The Coming of Age, trans. P. O’Brian (New York: Putnam's Sons, 1972), p. 284 .

2 The mechanisms influencing the perception of a person's age in a specific milieu are beyond the scope of this study. 
the winter of life. These generalizations have enabled individuals to monitor their conduct and to shape themselves according to such "codes."

In The Use of Pleasure, Foucault examines why sexual behavior, and the activities and pleasures which are dependent on it are made the object of moral concern. ${ }^{3}$ He sees this "problematization" in the Greco-Roman culture as one of the earliest aspects of a general history of "techniques of the self." His study of Greek and Latin prescriptive texts (the aphrodisia) from the fourth century $\mathrm{BC}$ and the first two centuries $\mathrm{AD}$ shows that sexual ethics was then part of a wider discussion of the proper use of pleasure and therefore linked to the question of self-mastery. Pleasures tending toward excess were said to lead to a form of enslavement; in contrast, a life of moderation (of power over one's pleasures) and self-mastery opened up a condition of individual freedom. Early Christian texts appropriated some of these views, such as the exaltation of continence, ${ }^{4}$ yet this exaltation does not have the same value in each culture. The Christian requirements of sexual austerity, for instance, became more coherent and authoritarian than in ancient philosophy; these requirements were subsequently "integrated with Christianity into the exercise of pastoral power, then later into educative, medical, or psychological practices." 5

Commenting on his investigation of the constitution of the self as a "subject of desire" in Greek and Roman Antiquity, and in early Christianity, Foucault notes in the preface of The Use of Pleasure:

It was a matter of seeing how an "experience" came to be constituted in modern Western societies, an experience that caused individuals to recognize themselves as subjects of a "sexuality", which was accessible to very diverse fields of knowledge and linked to a system of rules and constraints. What I planned, therefore, was a history of the experience of sexuality, where experience is understood as the correlation between fields of knowledge, types of normativity, and forms of subjectivity in a particular culture. (p. 4)

By "experience," Foucault means the "correlation of a domain of knowledge, a type of normativity, and a mode of relation to the self." ${ }^{6}$ The Use of Pleasure discusses relations between boys and mature men in Antiquity, but never addresses the question of love in old age. Such perspective,

\footnotetext{
3 Foucault, The Use of Pleasure, pp. 23-24.

4 Ibid. pp. 20-21.

5 The Foucault Reader, ed. Paul Rabinow (New York: Pantheon, 1984), p. 17.

6 The Foucault Reader, p. 333. See also Foucault, The Use of Pleasure, pp. 4-5.
} 
however, reveals an aspect of sexuality closely related to a system of social prohibitions and ethical values.

My focus will be on forms of relationship to self, on the practices through which one constitutes oneself as an object to be known, and on ways of speaking about love in old age. This chapter is about aged writers who acknowledge themselves as subject to desire while questioning the binary old-versus-young views. By finding new ways to articulate such commonplaces, their self-portraits had the capacity to disrupt these dichotomies and the "systems of thought" within which they worked. Petrarch addressed these questions within a Christian framework; with the graying of the courts and salons of the sixteenth century, however, the posture of the aged lover led Ronsard, Montaigne, and Pasquier to raise issues concerning social behavior, and to challenge the assumptions of the alternative between the lustful or the chaste old man. All four authors introduced nuance and leeway into rigid habits of thought epitomized by age stereotypes, and represented themselves as both old and young at the same time.

The authors in question do not offer faithful accounts of lived experiences; rather they are acute and astute readers of their own earlier texts. The emphasis will therefore be on their respective attitudes toward their vocation as writers, rather than on their eventual (and undocumented) psychological development.

\section{Petrarch}

Petrarch's writings have often been regarded as a manifestation of a new awareness of the flux of time, and with it of a new conception of subjectivity, ${ }^{7}$ yet critics have refrained from examining the moral and psychological effects of time on the poet's persona. I will be elaborating on previous findings to complement these contributions by looking at the impact of time on the writer's self-portraits as an aged lover in the Rime Sparse (or Rerum Vulgarium Fragmenta as Petrarch used to call this collection) and the Secretum.

Petrarch used to call his collection of love poems to Laura "little trifles" (nugellas) and his decision to write in the vernacular indicated that he did not put these at the same level as his most ambitious Latin productions.

7 Gurk Zak, Petrarch's Humanism and the Care of the Self (Cambridge: University Press, 2010), pp. 7-22 provides a good review of these comments. 
Yet, he kept putting together these scattered "fragments" up to his death, and had a lavish copy of the collection made.

From the poet-lover's confession of his "error" in the first poem of the Rime Sparse to his final prayer to the Virgin, conversion-involving death of a former self and spiritual rebirth-underlines the design of the collection as a whole:

Voi ch'ascoltate in rime sparse il suono

di quei sospiri ond'io nudriva 'l core

in sul mio primo giovenile errore, quand'era in parte altr'uom da quel ch'i' sono... spero trovar pietà, non che perdono.

You who hear in scattered rhymes the sound of those sighs with which I nourished my heart during my first youthful error, when I was in part another man from what I am now... I hope to find pity, not only pardon $(R$ 1, ll. 1-4, 8). 8

This experience introduces a radical discontinuity between the aged poet's devotion to God on the one hand, and his youthful and sinful passion for a woman, on the other hand. The distance of oneself from oneself is what becomes evident. This aspect deserves a closer look: rather than acknowledge his conversion to God in his later years, the poet describes a conversion of the "modality" of his gaze. As he grows old, his way of seeing love and himself has changed; yet, although he is aware of his spiritual derailment and repents, he is still "partly the same man." Laura is still the focus of his life, and the memory of his beloved keeps turning him away from the love for God. Throughout the Rime, anniversary poems commemorate the time that has elapsed since he saw Laura. According to this chronology, the poet was twenty-three years old when he first caught sight of a young married woman in the church of Saint Clare in Avignon on April 6, 1327 , and fell in love-a love that would last the rest of his life. He was aged forty-four when his lady died from the Black Death on April 6, 1348. Sixteen years after his first encounter, his desire remained as intense $(R 118)$; seventeen years later, and even twenty and twenty-one years later, he is still obsessed with her $(R 122, R 212, R 271, R 364)$.

In Sonnet 145, he acknowledges that regardless of where he is, or what happens to him, he remains the same: "still I shall be what I have been,

8 Petrarch, Lyric Poems. The Rime Sparse and Other Lyrics, ed. and transl. Robert M. Durling. (Cambridge, Mass.: Harvard University Press, 1976). All further quotations and translations are from this edition and are incorporated into the text. " $R$ " refers to "Rime". The first number refers to the poem number, the second one to the line number. 
shall live as I have lived, continuing my trilustral sighing" ("sarờ qual fui, vivrờ com'io son visso,/ continuando il mio sospir trilustre" ( $R$ 145, 1l. 13-14)). The collection tells of the circular nature of his desire and writing: "and new tears for old desires show me to be still what I used to be, not for a thousand turnings about have I yet moved” (“... et d'antichi desir lagrime nove/ provan com'io son pur quel ch'i' mi soglio,/ né per mille rivolte ancor son mosso" $R$ 118, 1l. 12-14). ${ }^{9}$ The cycle contains 366 poemsequal to the days in a calendar year, plus one day-but the new year epitomized by this additional day does not bring the poet a new life:

In questa passa 'l tempo, et ne lo specchio

mi veggio andar ver la stagion contraria

a sua impromessa et a la mia speranza.

Or sia che po: già sol io non invecchio,

già per etate il mio desir non varia ... $(R$ 168, ll. 9-13)

In the meanwhile time passes, and in the mirror I see myself nearing the season that is contrary to his promise and to my hope. Now come what will: I am not the only one who is growing old, and my desire does not vary at all with age...

His experience confirms the truth of a proverb he mentions in yet another poem: “one's hair will change before one's habits and human passions are no less intense because of the slackening of sense" $\left(R 122,11.5^{-7}\right) .^{10}$ The posture of the lover growing old is a traditional comic character, but the poet eliminates any such incongruity because he is his own judge. His lucidity recalls Petrarch's observation in his Letters of Old Age: "My very age and-unless I am mistaken - my even temper make me one of the fit judges. I know what I am." (Sen. VIII, 2, p. 274/ Lettres, vol. 3, p. 45).

Writing changes his self-perception because it puts Petrarch in front of other people's eyes: the poet feels that he is being watched; what was confused and subjective now becomes objective. Rather than making him a laughing stock, his painful self-awareness of the incongruity of his feeling puts his "error" in a Christian and moral perspective. At the same time, however, the compulsory confession of his sinful love becomes a pretext for endlessly telling every psychological nuance of the story of his spiritual derailment.

\footnotetext{
9 See Zak, Petrarch's Humanism and the Care of the Self, pp. 27, 45.

10 "Vero è 'l proverbio ch'altri cangia il pelo/ anzi che 'l vezzo, et per lentar i sensi/ gli umani affetti non sono meno intensi..." (R 122, ll. $\left.5^{-7}\right)$.
} 
In contrast to the Rime's wide circulation, the text that most clearly illuminates this process of self-examination and the protagonist's failure to convert is the Secretum (written in about 1547), which had a much more private diffusion. ${ }^{11}$ The Secretum is a fictitious dialogue between Franciscus (Petrarch) and Augustinus (Saint Augustine) in the symbolic form of a dream. Throughout their conversations, Augustinus- "a wise old man of venerable and majestic appearance" (p. 4) - epitomizes the aging Franciscus's consciousness, and probes his interlocutor in an attempt to ease his inner conflicts. Truth (reminiscent of Boethius's allegorical Philosophy) silently witnesses the exchanges. The work contains three books, dealing with the relations between will and desire (book I), the seven deadly sins (book II), and literary immortality and love (book III). Throughout these dialogues, references to Virgil, Cicero, and Seneca provide the foundations of a discussion that articulates alternative ways of life. Augustinus makes clear that Franciscus does not wish wholeheartedly to reform his life and be freed from earthly passions, hence the latter's unhappiness.

Book III focuses on Franciscus's confusion when it comes to love and ambition. Augustinus first takes up Franciscus's lifelong passion for Laura, and points out some early physical signs of his interlocutor's aging:

Have you seen yourself in a mirror recently?... Have you noticed how your face changes from day to day, and how some white hairs have already begun to appear on your head?... Has the sight of your changing body made any change at all in your mind?... White hair is a sign of approaching old age and a warning of death. (Secr. III, pp. 77-78)

Seemingly unaware of the brevity of human life, Franciscus replies by mentioning a number of famous men who serenely accepted the graying of their temples at an early age. He fails to understand that death is already upon him; indeed, his reading of signs is superficial. For Augustinus on the other hand, growing old means ordering one's desires (as Seneca observed in Ad Lucil. 20, 5) and dedicating oneself to enduring, spiritual values. The saint says to his interlocutor, "be ashamed to be called an

11 Petrarch, Secretum, ed. Enrico Carrara, in Petrarch, Prose, ed. Guido Martellotti, P. G. Ricci, et al. (Milan and Naples: Ricciardi, 1955), pp. 21-215. I have also consulted Il mio Segreto, ed. Ugo Dotti (Milan: Rizzoli, 200o). All English quotations refer to My Secret Book, transl. J. G. Nichols (London: Hesperus, 2002) and are incorporated into the text. The first number indicates the book number, the first page number refers to the English edition. When needed, I have added a second page number indicating the Latin edition. I have also consulted Carol E. Quillen's translation, The Secret (New York: St Martin's Press, 2003). 
elderly lover. Be ashamed that for so long you have been the talk of the town" (Secr. III, p. 80)..$^{12}$ His remark directly echoes the Rime's first sonnet $(R$ 1, ll. 9-11). Augustinus's argument remains the classical one of attaining self-mastery over the passions. The pursuit of self-control and virtue in this life helps secure an individual's place in the next. Only by rejecting earthly distractions and false pleasures will Franciscus find true happiness in God. Echoing the inner struggles of Laura's lover in the Rime sparse, Augustinus keeps urging Franciscus: "You should [...] be ashamed that your state of mind has not changed while your body has been continually changing" (III, p. 81). ${ }^{13}$

In the Rime, the lack of chronological organization of the poet-lover's narrative reflects his spiritual confusion. Rather than offering a coherent story of his passion, he juxtaposes fragments of different moments of his life. Like the aged poet of the Rime, Franciscus recognizes that he is responsible for his own destruction, yet he clings to it. He exhibits the stereotypical difficulty of old people in changing their longtime habits and behaviors. After three days of conversation with Augustinus, Franciscus is still moving in the wrong direction, and the end of the last dialogue lacks decisive closure. Augustinus asks God to help his interlocutor "reach safety," and Franciscus hopes that "the storm in [his] mind will die down [...], and Fortune stop troubling [him]" (III, p. 93). For the reader, the lesson is straightforward: Franciscus is to watch over himself-his behavior, his thoughts, and his soul. The dialogue points out human beings' freedom of choice, while also stressing that whoever wishes to discard his unhappiness has to devote himself to God (I, p. 7). ${ }^{14}$ In spite of Augustinus's efforts, however, Franciscus echoes the poet-lover of the Rime, and acknowledges that "the root of [his] unhappiness is in [his] will." (I, p. 11).

Both texts champion a conception of love capitalizing on caritas. Both of them urge the poet to find joy in God, and to avoid earthly pleasure that cause the soul's distraction, dispersion, and dissipation. For Laura's lover in the Rime, as well as for Franciscus, old age brings a particular poignancy to the concern for death and the afterlife. Along with this spiritual

12 "Pudeat ergo senem amatorem dici; pudeat esse tam diu vulgi fabula" (Secr. III, p. 65).

${ }_{13}$ On this passage, see Zak, Petrarch's Humanism and the Care of the Self, pp. $5^{2-58}$.

14 On the lack of any reference to Grace, see Carol E. Quillen, Rereading the Renaissance. Petrarch, Augustine, and the Language of Humanism (Ann Arbor: University of Michigan, 1998), pp. 182-216. 
growth, the portrait of the writer in the winter of his life conveys a sense of self-awareness.

\section{Ronsard}

In the Rime, old age brought the poet a feeling of loss, dependency, loneliness, and depression. Approximately two centuries later, Pierre de Ronsard ironically commented on Petrarch's self-portrait as a transfixed and weeping lover, deliberately blurring the distinction between the Tuscan author and his poetic persona. In Ronsard's view, anyone with common sense would find the Rime's story of endlessly frustrated love and inner struggles quite insane:

Ou bien il [Pétrarque] jouyssoit de sa Laurette, ou bien

Il estoit un grand fat d'aimer sans avoir rien.

Ce que je ne puis croire, aussi n'est-il croyable:

Non, il en jouyssoit: puis la fist admirable,

Chaste, divine, saincte... (I, pp. 168-69) ${ }^{15}$

Either he (Petrarch) had sex with his little Laura, or he was a big fool to love without having anything, which I cannot believe; indeed, it is unbelievable. No, he had sex with her; then he made her admirable, chaste, divine, saintly....

Surely, Petrarch "committed no such sin, remaining in love with his lady for thirty-one years, without any other ever being able to warm his soul," Ronsard adds ironically (I, p. 168). ${ }^{16}$ His blatant distortion of Petrarch's moral and Christian framework was a way to set himself up as the champion of inconstancy. In a time of renewed interest in Petrarch and Petrarchan poetry with a Neo-Platonist flavor in French aristocratic salons, Ronsard managed to sound out new resonances from Petrarch's Canzoniere. While competing with the young Philippe Desportes's verses of Amours de Diane and Amours d'Hippolyte (published in his Oeuvres, 1573), Ronsard's Sonnets pour Hélène (1578) reflected the complex situation of an aged poet adopting the posture of a lover. In book II of Castiglione's influential

15 Pierre de Ronsard, CEuvres, ed. Jean Céard, Daniel Menager, and Michel Simonin (Paris: Gallimard, 1993) vol. 1, pp. 168-69. All further references are to this edition and are incorporated into the text. All translations of Ronsard's poems are my own.

16 "le bon Petrarque un tel peché ne fist/ Qui fut trente et un an amoureux de sa dame, / Sans qu'un autre jamais luy peust eschauffer l'ame". On this point, see Sara Sturm-Maddox, Ronsard, Petrarch, and the "Amours" (Gainesville: University Press of Florida, 1999), pp. 84-89. 
Libro del Cortegiano, the young Federico Fregoso cruelly mocked the old man writing love letters to young girls (II, p. 77). ${ }^{17}$ Yet such was the situation of a growing number of aging French poets in the second half of the sixteenth century-including Ronsard himself. Many of them were probably not really in love; nevertheless, they were expected to write love songs in spite of their lined faces.

For Georges Minois, Ronsard's poetry epitomizes the Renaissance general cult of youth, and contempt for old age. ${ }^{18}$ His thesis does not take into account Ronsard's multiple perspectives on age and his tendency to elaborate on a wide variety of texts and commonplaces on Time's flight. ${ }^{19}$ Interestingly, the word "vieillesse" (old age) and its derivatives appear more than six hundred times throughout Ronsard's work, whereas words related to "young" and "youth" ("jeune" and "jeunesse") appear more than eight hundred times. ${ }^{20}$ At about age thirty, the poet notes the first signs of his physical decline: some gray hair, a balding head, blackened teeth, and a cold body. He blames his love torments and his addiction to work for precipitating the aging process (I, pp. 959, 816, 806-7).

The Sonnets for Hélène provide a suggestive way to explore Ronsard's posture as an aged poet in love. He was fifty-four years old when his collection first appeared, in 1578. My discussion will refer to this work's last version, published in the 1584 edition of the OEuvres, one year before the poet's death. At that time, Ronsard was "starting to be inconvenienced by age's woes," in the words of Jacques Davy Du Perron ("commençant à se trouver incommodez des accidens de la vieillesse"). ${ }^{21}$ He incorporated a series of poems from the Amours diverses stressing his physical decline into the Sonnets pour Hélène. Furthermore, he explicitly stated his agefifty-six-in the dedicatory epistle to Neufville de Villeroy that precedes the Amours diverses, right after the Sonnets pour Hélène.

In his Vie de Ronsard that appeared shortly after the poet's death, Claude Binet noted that the cycle of poems for Hélène was written at the request

\footnotetext{
17 See chapter 2, the section on Castiglione.

18 Georges Minois, Histoire de la vieillesse en Occident de l'Antiquité à la Renaissance, pp. 339-64.

19 See Malcolm Quainton, Ronsard's Ordered Chaos. Visions of Flux and Stability in the Poetry of Pierre de Ronsard (Manchester: Manchester University Press, 1981), pp. 131-225.

20 Alvin Creore, $A$ Word-Index to the Poetic Works of Ronsard (London: Laney and Son Ltd, 1972).

21 J. Davy Du Perron, Oraison funèbre sur la mort de Ronsard, ed. M. Simonin (Geneva: Droz, 1985), pp. 105-6.
} 
of Catherine de Medici. ${ }^{22}$ Did the queen really ask Ronsard to compete with Petrarch's Canzoniere as Binet contends? Her intervention is doubtful, yet Ronsard's careful attention to Petrarchan writing practices, among many other references, is undeniable. ${ }^{23}$ In Petrarch's Rime Sparse, the young poet's pale face and melancholy reflect his endless love torments. In Ronsard's sonnets on the other hand, these signs refer to the lover's age. Indeed, a gloomy mood and an unhealthy condition are commonplaces in elders' portraits (I S 14, S 22; II, S 1, 2, 21, 24). ${ }^{24}$ The aged Tuscan protagonist was ashamed of his "youthful error;" Hélène's lover playfully inverts the expression of this feeling, while acknowledging that old age has caught up with him. He regrets the physical limitations imposed by advancing age when it comes to sensual pleasures:

J'ay honte de ma honte, il est temps de me taire,

Sans faire l'amoureux en un chef si grison... (II S 36, p. 397)

I am ashamed of my shame, it is time to fall silent, without playing the lover with such a gray head...

Now that he is in his fifties, it is time for him to follow Reason's law-that is, to go home and give up love (II, S 36 ) - or, rather, to give up writing love poetry. Whether his irony betrays his real pain and irritation at growing old is a moot point. Like a palimpsest, the sonnets unmask and subvert the hypocrisy of the poetic conventions to which they refer. Petrarch elaborated on the homophony between his beloved's name (Laura) and his poetic inspiration (l'aura); Ronsard too uses puns-he represents himself out of breath (hors d'haleine), painfully climbing the palace's stairs to meet Hélène. Instead of portraying himself as a helpless victim of love's fatal glance-another stereotype of Petrarchan verses and of the French medieval amour courtois - from the outset, he contends that his attraction to his lady is the result of a deliberate choice:

Vous seule me plaisez, j'ay par election

Et non à la volée aimé vostre jeunesse:

Aussi je prens en gré toute ma passion,

Je suis de ma fortune autheur, je le confesse. (I S1, p. 341)

22 Claude Binet, La vie de Pierre de Ronsard, ed. P. Laumonier (Geneva: Slatkine Reprints, 1969), p. 26.

23 Sarah Sturm-Maddox, Ronsard, Petrarch, and the "Amours", pp. 90-127.

24 The references indicate the Sonnets pour Hélène's book number (I or II), the sonnet number $(\mathrm{S})$, and the page number. 
You alone please me; I have by choice, not frivolously loved your youth: thus all my suffering pleases me. I confess that I am the author of my fortune.

His freedom of expression is the privilege of his age. He warns Hélène that he can find love elsewhere and bluntly tells her that she will be his last love affair ("derniere aventure," I, S 1, p. 341). ${ }^{25}$ He claims that he can control his feelings, although in other sonnets he acknowledges his impossibility not to love Hélène, thereby complying again with the Petrarchan conventions of love poetry. As critics have noted, Ronsard's denunciation of the topos of the chaste and faithful lover refers to a classical as well as to a French tradition celebrating sensual pleasures. ${ }^{26}$ Yet scholars have failed to notice how Ronsard capitalizes on his age in this respect. Boasting of his long experience, he acknowledges the illusory nature of love while fully enjoying such illusion. Moreover, he reacts to Hélène's Platonic conception of love as an old hedonist, repeatedly telling her that neither beauty nor youth last forever. He avoids any graphic descriptions of his physical decline, but warns Hélène of the flight of time. Her face will wrinkle, her body will lose its appeal, he notes; Hélène's old age will be like a shameful illness, and will force her to abandon all hope of being loved and celebrated in songs (II, S 43, pp. 400-1). She must comply with the moral code of the day, and the old lover is ready to break off if she does not: "Should virtue deceive me, farewell fair Mistress" ("Si la vertu me trompe adieu belle Maistresse" (I, S 1, p. 341).

In his posthumous biography of Ronsard, Claude Binet took great care to stress the chastity of the old poet's love for Hélène. ${ }^{27}$ This clarification corresponded to the climate of moral austerity in Catholic as well as Protestant circles. $^{28}$ Did Hélène de Surgères also put pressure on Binet in this respect? She was so concerned about her reputation that she asked Jacques

25 Ronsard ironically misquotes a line by Desportes inspired by Petrarchan and NeoPetrarchan sources. See Sonnets pour Hélène, ed. Malcolm Smith (Geneva: Droz, 1998), p. 30 , fni4.

${ }_{26}$ See Véronique Denizot, Ronsard. "Les Amours" (Paris: Gallimard, 2002), pp. 7-9, 129-30.

27 See Binet, La vie de Pierre de Ronsard, pp. 25-26. "Apres avoir chanté divers subjects il [Ronsard] voulut finir et couronner ses œuvres par les Sonets d'Helene, les vertus, beautez, et rares perfections de laquelle furent le dernier et plus digne object de sa Muse, le dernier parce qu'il n'eust l'heur de la voir qu'en sa vieillesse, et le plus digne parce qu'il surpassa aussi bien que de qualité, de vertu, et de reputation les autres precedens sujectz de ses jeunes amours, lesquels on peut juger qu'il aima plus familierement, et non cetuy-cy qu'il entreprit plus d'honorer et louer, que d'aimer et servir."

28 Ronsard, CEuvres, I, p. 1357. 
Davy Du Perron to add an introductory epistle to Ronsard's collection, stating that the poet's love for her was not "impudique" (immodest). Du Perron declined her request, replying, ironically, that Hélène's portrait was enough to rule out such suspicion. ${ }^{29}$ In the same way, Ronsard's ludic perspective on love in old age echoes the witty tone of courts' and salons' entertainments, and demonstrates the genius of a poet who capitalized on his age to renew the fashionable clichés of the day.

Interestingly, today's gerontologists observe that old age encourages an ironic perspective on the world, on others, as well as on oneself, 30 but Ronsard's collection for Hélène also emphasizes the aging poet's greater capacity for empathy. His defense of peace and his condemnation of hatred (two recurring themes in Ronsard's later poetry as a whole) are at the heart of his relations with his beloved. Conceived and published in a context of civil wars, his canzoniere conveyed a message of reconciliation and tolerance, even if an ideal agreement between Ronsard's aged persona and the young Hélène did not often seem possible. ${ }^{31}$

To young rivals such as Desportes, Ronsard's self-representation as an aged lover in the Sonnets pour Hélène was a masterful display of imagination, rhetorical skill, and erudition. Ronsard's self-portraits in the winter of his life were a pretext for poetic games, but old age was also a source of distress and melancholy that brought excruciating pain, as Ronsard claimed in the "Ode to Christofle de Choiseul" among several similar texts:

Non, ce n'est moy qui veut or'

Vivre autant que fist Nestor:

Quel plaisir, quelle liesse

Reçoit l'homme en sa vieillesse,

Eust-il mille talens d'or?

L'homme vieil ne peut marcher,

N'ouyr, ne voir, ny mascher:

C'est une idole enfumée

Au coin d'une cheminée,

Qui ne fait plus que cracher.

29 Perroniana, article "Gournay" (Cologne, 1694), p. 178.

30 See W. L. Randall and E. McKim, Reading our Lives. The Poetics of Growing Old (Oxford: Oxford University Press, 2008), p. 15.

31 See Sara Sturm-Maddox, Ronsard, Petrarch, and the "Amours", pp. 116-27. In a similar way, a posthumous sonnet published in the 1587 edition of the CEuvres represents two lovers growing old together: "Vous estes déjà vieille, et je le suis aussi./ Joignon nostre vieillesse et l'accollon ensemble,/Et faison d'un hyver qui de froidure tremble/(Autant que nous pourrons) un printemps adouci." (I, p. 507). 


\begin{abstract}
Il est tousjours en courrous Bacus ne luy est plus doux, Ny de Venus l'accointance: En lieu de mener la dance Il tremblote des genoux.
\end{abstract}

Si quelque force ont mes voeux, Escoutez, Dieux, je ne veux Attendre qu'une mort lente Me conduise à Rhadamante Avecques des blancs cheveux. (I, p. 902)

No, now I do not want to live as long as Nestor. What pleasure, what joy, does man receive in old age, even if he has a thousand golden talents? The old man cannot walk, nor hear, nor see, nor chew; he is a smoked form beside a fireplace, who only spits. He is always angry; does not find Bacchus sweet, neither Venus; instead of leading the dance; his knees are shaking. If my wishes have some power; Listen Gods, I do not want to wait for a slow death to lead me to Rhadamantus with white hair.

Whether the poet was telling the truth or not is a moot point. One thing, however, is certain: these complaints were part of Ronsard's efforts to win his patrons' support. In a poem dedicated to the Cardinal of Lorraine, the poet speaks of his sad and lethargic state of mind in the winter of his life (I, pp. 511-12). He is too old for love affairs, hence he has no poetic inspiration, and his existence no longer has any meaning. ${ }^{32}$

The wide range of tones of his self-portraits in old age confirms his belief that a fundamental law of transformation governs all living organisms. Likewise, metamorphosis reigns over his own poetic microcosm: as the years pass, Ronsard changes his skin, like a snake, as he puts it in a posthumous sonnet of the 1587 edition of his OEuvres (I, p. 507). In the Sonnets for Hélène, the poet refers to yet another metamorphosis, which also granted him immortality: while his body keeps aging, his love song for Hélène has the mythological permanence of Tithonus's songs (II, S 1 ). ${ }^{33}$

Similarly, Claude Binet's and Jean Galland's orchestration of Ronsard's posthumous collection Les Derniers vers capitalizes on metamorphosis to praise the poet's immortal glory. The first sonnets present the old and sick Ronsard "dictating and praying and dying altogether" ("dictant et priant

\footnotetext{
32 See François Rouget, "Ronsard et la vieillesse: expérience et représentation," in Vieillir à la Renaissance, ed. C. H. Winn and C. Yandell (Paris: Champion, 2009), pp. 93-105.

33 Eos had asked Zeus to give Tithonus, her mortal lover, the gift of immortality, but forgot to ask also eternal youth. Zeus changed Tithonus into a cicada.
} 
et mourant tout ensemble") in the editors' words. ${ }^{34}$ In the following sonnets, the poet's soul progressively liberates itself from his suffering body. As Ronsard's soul finds eternal rest, his most divine part-his poetryremains eternally young, perpetually renewing itself.

The imaginative versatility of Ronsard's self-portraits as an old man challenges any attempt to encapsulate them in one sentence. These representations confirm the truth of a French sixteenth-century proverb: "C'est grand peine que d'estre vieux: Mais il ne l'est pas qui veut" ("It is very painful to be old, but no one chooses it"). ${ }^{35}$

\section{Montaigne}

Petrarch's and Ronsard's self-portraits opened up the stereotypes of the chaste old man and the lustful elder to new literary and psychological insights. Montaigne, on the other hand, had a more pragmatic perspective on these questions. Like Petrarch and Ronsard, however, he viewed sexual love in terms of identity in the chapter "On some verses of Virgil" (III, 5). "Each one of my parts makes me myself just as much as every other one," he writes. Speaking of his sexual organ, he adds, "no other makes me more properly a man than this one" ("Chacune de mes pieces me faict esgalement moy que toute autre. Et nulle autre ne me faict plus proprement homme que cette cy," III, 5, p. 887/p. 822).

Scholars have seen in this chapter a criticism of the Neo-platonic perspective on love championed by Ebreo, Ficino, and Bembo. ${ }^{36}$ Montaigne mentions all three names in his essay, yet critics have omitted one aspect of his discussion, which concerns his intimate comments on sex and old age. In this respect, Montaigne's self-portrait as an aging man gives an ironic twist to the speech that Bembo-the fictional character that Castiglione modeled after the real Bembo-delivers on intellectual love and reason at the end of book four of the Courtier. Montaigne's remarks playfully elaborate on the reaction that Bembo's speech elicits from signor

34 Pierre de Ronsard, CEuvres complètes, ed. P. Laumonier, R. Lebègue, and I. Silver (Paris: STFM, 1914-74), vol. 18, p. 174. See also Rouget, "Ronsard et la vieillesse: expérience et représentation," pp. 93-105.

35 Jean Nucerin, Proverbes communs et belles sentences pour familièrement parler françois à tout propos, tres utiles et necessaires à toutes gens, composez par I. Nucerin (Paris: Picard, 1960), no page numbers.

36 See Barbara Bowen, "Montaigne's anti-Phaedrus: 'Sur des vers de Virgile' (Essais III, 5)” Journal of Medieval and Renaissance Studies 5, 1(1975), pp. 107-22. 
Morello: "without the body, love is a fantasy" (IV, p. 247) ${ }^{37}$ Montaigne only mentions Castiglione twice in the Essais; however, critics have pointed out numerous allusions to the Book of the Courtier throughout his work. In the chapter "On some verses of Virgil" (Essais, III, 5), which is my focus here, Montaigne's criticism of male hypocrisy towards women and marriage elaborates on the remarks made by Magnifico Giuliano in the third book of the Courtier. ${ }^{38}$ Such references indicate that the essayist consulted the 1585 Gabriel Chappuis French translation. ${ }^{39}$ In addition, Estienne de La Boétie, Montaigne's cherished friend, owned an Italian copy of the treatise, as did many members of the French upper classes.

Since the explicit theme of The Book of the Courtier is learning how to represent oneself-or rather an abstract self-to one's peers and to the prince, the courtier is required to deal with the social meaning of his age. In contrast, Montaigne situates the question of aging in a reflexive perspective, since he is the focus of his own work. Stressing his alleged withdrawal from the public sphere in a time of religious turmoil and civil wars, he claims to spend his later years with his books in the retreat of his castle, away from any political and professional obligations. At the same time, however, Montaigne's construction of his personal identity also emerges out of and through the representation of social relationships.

Never does Montaigne hide his age - quite the contrary, especially in the chapter "On some verses of Vergil": "an avowed ugliness and old age is less old and less ugly to [his] taste than another that is painted and glossed over," he writes ("Une laideur et une vieillesse advouée est moins vieille et moins laide à mon gré qu'une autre peinte et lissée," III, 5 , p. 895/p. 829). At the outset of this chapter, the essayist, who is in his fifties, considers his life both in terms of the past-looking back from old age - and the future-looking forward from youth. He sadly observes that age and illness have weakened his body and darkened his mood (III, 5, p. 842/p. 775). The number of his pleasures has decreased over time, although his sensitivity to their sensual qualities has actually increased in later life (III, 5, p. 843/p. 775). After some digressions his thoughts focus on sexual love, and he remarks on the pervasive social and moral hypocrisy surrounding such a vital and natural action. The use of literary quotations

\footnotetext{
37 See chapter 2, the section on Castiglione.

38 See Géralde Nakam, Montaigne. La Manière et la Matière (Paris: Champion, 2001), p. 141.

39 See Marcel Tetel, "The Humanistic Situation. Montaigne and Castiglione," The Sixteenth Century Journal 10, 3 (1979), pp. 64-84.
} 
allows Montaigne to add one more layer of comments on a matter he views as an essential part of his being, and indeed of life itself. At the end of the chapter, he reconsiders the misfortunes of his aging self and fantasizes on a way to cure his melancholy. A love affair, he observes, would cheer him up by bringing back his youthful energy and gaiety; yet he rejects this option as unrealistic on the basis of his age, for love is the privilege of youth. Furthermore, Montaigne's appearance and poor health do not give him any hope of seducing an attractive young woman.

This conclusion ironically provides a means of diverting his troublesome thoughts: he reads erotic verses from Virgil and Lucretius; the suggestive power of poetry awakens his sexual desire and chases away the gloom of old age. What he describes is a conscious effort by the mind to evoke the sexual pleasures that came spontaneously in youth. The reading of poetry enables him to obtain certain effects he can control at will, and whose intensity may even prove superior to actual sexual love. "Venus is not so beautiful all naked, alive, and panting, as she is here in Virgil," he contends ("Venus n'est pas si belle toute nue, et vive, et haletante, comme elle est icy chez Virgile," III, 5, p. 849/p. 782). But as he is well aware from the outset, his attempt is doomed to failure, for it is only a substitute for love:

Je ne m'esgaye qu'en fantasie et en songe, pour destourner par ruse le chagrin de la vieillesse. Mais certes il y faudroit autre remede qu'en songe: foible luicte de l'art contre la nature. (III, 5, p. 842)

I am merry only in fancy and in dreams, to divert by trickery the gloom of old age. But indeed it would require another remedy than a dream: a feeble struggle, that of art against nature. (p. 775)

He lucidly understands that this is the only means at his disposal to stimulate his mind and thereby to experience again some remnant of his youthful desire. ${ }^{40}$ "It is unjust to excuse youth for following its pleasures and to forbid old age to seek any," he notes in "Of Vanity" ("C'est injustice d'excuser la jeunesse de suyvre ses plaisirs, et deffendre à la vieillesse d'en cercher," III, 9, p. 977/p. 908). Old age's pleasures correspond to an increasingly demanding taste, and require more creativity since they are fewer. Montaigne's quest for pleasure is active in this respect and thus quite different from these decrepit men longing for their past physical vigor, whom Plato describes as nostalgically watching young athletes

40 See Olivier Guerrier, Quand "les poètes feignent": "fantasie" et "fiction" dans les "Essais" de Montaigne (Paris: Champion, 2002), pp. 256-78; and Mary McKinley, Words in a Corner. Studies in Montaigne's Latin Quotations (Lexington: French Forum, 1981), p. 80. 
(III, 5, p. 842/p. 775). The essayist feels too old for a love affair but compensates this loss by his vivid imagination: he becomes an expert at mentally increasing the intensity of sexual desire's effects. His fictitious pleasures correspond better to his aged and ailing body's limitations. Moreover, in contrast to youthful impatience, he now thoroughly enjoys the detours and the delays of love games (pp. 880-81/pp. 818-19).

By acknowledging the persistence of his sexual desire over the years, Montaigne questions the cliché of the chaste old man. His comments refer more specifically to Bembo's speech at the end of the fourth book of Castiglione's Libro del Cortegiano. Following a classical view (expressed in Plato's Phaedrus among other sources), Bembo praises the chastity of the aging courtier, free from the yoke of his youthful sexual desire and reaching the highest form of spiritual love through reason. This experience culminates in a contemplation of pure beauty, bringing the aged courtier close to divine perfection (IV, pp. 257-58). For Montaigne, this attitude turns us into insensitive beings who can no longer feel their bodies. Commenting on similar abstract views, he notes in another chapter:

Ils veulent se mettre hors d'eux et eschapper à l'homme. C'est folie: au lieu de se transformer en anges, ils se transforment en bestes; au lieu de se hausser, ils s'abattent. Ces humeurs transcendentes m'effrayent...("Of Experience," III, 13, p. 1115)

They want to get out of themselves and escape from the man. That is madness: instead of changing into angels, they change into beasts; instead of raising themselves, they lower themselves. These transcendental humors frighten me.... (p. 1044)

For Bembo, the old courtier, driven "by the force of his own imagination" makes a woman's "beauty much more beautiful than in reality it is" by situating it in a purely intellectual perspective (IV, p. 255). Bembo's description of love is in fact the overcoming and ending of the erotic experience of an ideal individual who possesses almost superhuman discipline and skills. In "Some verses of Virgil" on the other hand, Montaigne sees the abstract love of love praised in Bembo's speech as inconsistent, and puts it upside down: the essayist's imagination produces sensual and erotic images of women.

This is doubtless a reminder that physical, non-intellectual elements stimulate the author's creative energy. Furthermore, the essayist's personal experience proves more versatile than abstract age-related categories would lead us to believe. Indeed, the chapter challenges static accounts of the "life cycle" as a succession of fixed and repetitive stages-youth, 
old age - with a uniform and homogeneous set of binary oppositions. As Montaigne physically ages, his mind rejuvenates. To paraphrase mildly his own words, old age "puts more wrinkles on his body than in his mind" (III, 2, p. 816/p. $\left.75^{2}\right) \cdot{ }^{41}$ In "Some verses of Virgil," he describes himself as occupying his days with "toys and pastimes, like childhood" ("jouer aux noisettes et à la toupie," III, 5, p. 842/p. 776) to divert the gloom of old age. He knows very well that the reading of erotic Latin verses does not replace sex, but the fictitious nature of his game suggests that love is mostly the product of an illusion.

His experience was not lost on André Gide, an avid reader of the Essais. In his Journal, the seventy-two-year-old Gide writes on March 6, 1941:

Mon âme est demeurée jeune à ce point qu'il me semble sans cesse que le septuagénaire que je suis indubitablement, c'est un rôle que j'assume; et les infirmités, les défaillances qui me rappellent mon âge, viennent à la manière du souffleur, me le remettre en mémoire lorsque je serais enclin à m'en écarter. Alors, comme un bon acteur que je veux être, je rentre dans mon personnage et me pique de le bien jouer. Mais il me serait beaucoup plus naturel de m'abandonner au printemps qui vient; simplement je sens que je n'ai plus le costume qu'il faut pour cela. ${ }^{42}$

My soul has remained so young that I have the continual feeling of playing the part of the seventy-year-old that I certainly am; and the infirmities and weaknesses that remind me of my age act like a prompter, reminding me of my lines when I tend to stray. Then, like the good actor I should like to be, I go back into my role, and I pride myself on playing it well. But it would be much more natural for me to abandon myself to the coming spring: I simply feel that I no longer have the costume that it calls for.

A soul cannot concentrate continuously on serious matters, Montaigne observes, in fact it is for old persons "to trifle and play the fool, and for the young to stand on their reputation" ("C'est à nous à resver et baguenauder, et à la jeunesse de se tenir sur la reputation,” III, 5, p. 843/p. 776). From Antiquity to the Renaissance and to our time, this behavior seems one of old age's constant features. "Childhood goes, but childishness remains," Seneca wrote to Lucilius (Ad Lucilium 4, 2). This can be seen as a transition to another valued role, as Gide points out: that of the senex puer (the childish old man) who knows there is nothing to be got and enjoys a bearable present by delighting in trifles. In "On some verses of Virgil," this

\footnotetext{
41 Montaigne's words are: “Old age puts more wrinkles in our minds than on our

42 André Gide, Journal 1939-1949. Souvenirs (Paris: NRF, 196o), pp. 71-72. My translation.
} faces." 
posture rejuvenates Montaigne's perspective but affects his relationship with himself since it is the sign of a wisdom acquired from long experience. It prevents the aging essayist from "kicking and grumbling against the discomforts that nature orders [him] to suffer, but not from feeling them" ("regimber et gronder contre les inconvenients que nature m'ordonne à souffrir, mais non pas de les sentir," III, 5, p. 843/pp. 776-77). For him, wisdom is inherently of a "gay and pleasant quality" (III, 5 , p. 844/p. 778). Quoting Sidonius Apollinaris, he observes that "Gloomy things should be lightened with pleasantries" ("tetrica sunt amaenanda jocularibus," III, 5, p. 844/p. 778), and criticizes the portrait of old Crassus who "was never seen to laugh" (III, 5, p. 845/p. 778).

Following Cicero's De Senectute, Castiglione's fourth book of the Courtier represents the elder courtier as embodying the moral and political values of his social milieu (IV, pp. 238-40). Montaigne's self-portrait has no such didactic goal. ${ }^{43}$ Observing that his first edition was in the year 1580 , he adds:

Depuis d'un long traict de temps je suis envieilli, mais assagi je ne le suis certes pas d'un pouce. Moy à cette heure et moy tantost sommes bien deux; mais quand meilleur, je n'en puis rien dire. Il feroit beau estre vieil si nous ne marchions que vers l'amendement. C'est un mouvement d'yvroigne titubant, vertigineux, informe, ou des joncs que l'air manie casuellement selon soy. ("Of Vanity," III, 9, p. 964)

Since then I have grown older by a long stretch of time; but certainly I have not grown an inch wiser. Myself now and myself a while ago are indeed two; but when better, I simply cannot say. It would be fine to be old if we traveled only toward improvement. It is a drunkard's motion, staggering, dizzy, wobbling, or that of reeds that the wind stirs haphazardly as it pleases. (pp. 894-95)

For Montaigne, the question of love in old age should be addressed in terms of tactics and practices of everyday life, rather than via ideology or compliance with a set of coded behaviors. Since later life is a time of physical decline, it requires adaptability. ${ }^{44}$ The posture of the senex puer epitomizes such flexibility of the mind. Fantasizing about sex through the suggestive erotic power of Latin poetry may indeed be a vain exercise for a senior, but the very possibility of entertaining these youthful thoughts has

43 "Others form man; I tell of him, and portray a particular one, very ill-formed, whom I should really make very different from what he is if I had to fashion him over again", he remarks at the opening of the chapter "Of Repentance" (III, 2, p. 804/740).

44 See chapter 4 , section 3 on this aspect. 
a therapeutic effect that capitalizes on the mind's inconstancy, and thus on its ability to divert the gloom of old age. The success of this tactic, however, is relative, for it cannot undo the cause of Montaigne's melancholythe biological process of aging - and its effect wears off with time.

As Montaigne grows old, he places sexuality in the broader context of various forms of pleasures, and dispels many prejudices. He feels different from in his youth, but neither inferior nor superior to what he once was. In "Some verses of Virgil" he describes himself as having less vigor and vivacity than in his youth, but finds that he has more time for cultivating the present instant. ${ }^{45}$ This is a heuristic, experimental approach that puts its faith in aging as a productive period of life. What Montaigne acquires through his experience of aging, whereby he sees himself and the world with different eyes from those of the youth, is frankness; indeed, he is quick to point out that old people are traditionally granted more freedom of speech than young ones. In "On some verses of Virgil," this freedom is obvious in his focus on sex-a rather contentious and shocking topic, as he remarks. Throughout this chapter, Montaigne acknowledges aging as problematic and attempts to create forms more adequate to such a complex experience. The standard oppositions of old age and youth, wisdom and folly, lust and chastity prove irrelevant when applied to the later life of a particular individual. The essay (a genre in many ways related to the dialogue) gives Montaigne a flexible way to register the ambiguities and ambivalences of his aging self.

In this respect, "On some verses of Virgil" stresses the difficulty of being both the object and the subject of a discussion on a topic such as age. For if the speaker is old, as Montaigne observes elsewhere,

il ne peut juger du sentiment de la vieillesse, estant luy mesme partie en ce debat; s'il est jeune, de mesme; sain, de mesme; de mesme, malade, dormant et veillant. Il nous faudroit quelqu'un exempt de toutes ces qualitez, afin que, sans praeoccupation de jugement, il jugeast de ces propositions comme à luy indifferentes; et à ce conte il nous faudroit un juge qui ne fut pas. (“Apologie de Raymond Sebond," II, 12, p. 600)

he cannot judge the sense perception of old age, being himself a party in this dispute; if he is young, likewise; healthy, likewise; likewise sick, asleep, or awake. We would need someone exempt from all these qualities, so that with an unprejudiced judgment he might judge of these propositions as of things indifferent to him; and by that score we would need a judge that never was. (p. 552)

45 See chapter 4 , section 3 on this aspect. 
"On some verses of Virgil" questions abstract representations of old age yet does not challenge social decorum and convenances. Throughout this essay, sexual love is essentially a reading and writing experience rather than a real one. ${ }^{46}$ In addition, Montaigne's lucid self-analysis eliminates the risk of associating himself with those aging lovers whom Federico, in the Book of the Courtier (II, p. 78), accuses of making fools of themselves. Montaigne's self-portrait here is not a dialogue, like Castiglione's work, yet it also is conceived as a social game. This game is based on conversations with books rather than with a lively circle of aristocrats gathered at the court of Urbino, but like Castiglione's conversations, Montaigne aims at stimulating his readers' imagination-especially the imaginations of young and beautiful women - as much as his own. With this targeted audience, he establishes a friendly relation, quite similar to the witty exchanges between Castiglione's protagonists, with their light-hearted way of teasing one another. To these implied readers-his accomplices-Montaigne addresses a humorous plea for their understanding and affection. He asks to be esteemed for who he is, for his wit, his honesty, his determination to rid his mind of despair, and his efforts to unmask the hypocrisy of stereotypes of love in old age. He also advocates friendly relations between men and women, youth and elders. Obviously, he would be the first to reap the reward of this strategy of seduction.

Ironically, in "On some verses of Virgil" the aging Montaigne displays the social and intellectual qualities of Castiglione's young courtier. He gracefully adapts to all circumstances, even those whose effects are out of his control, such as growing old; his conversation proves both sound and entertaining (especially for women); he perceptively stresses his own value without being pretentious or offensive. He has the same aesthetic sense of negligence and effortlessness that the youthful courtier is required to portray in order to obtain recognition, praise, and favor. Montaigne's frankness and his refusal of artificiality are a form of sprezzatura, the master trope of the courtier. Castiglione's Count Ludovico defines it in the following terms: "to conceal all art and make whatever is done or said appear to be without effort and almost without any thought about it." (I, p. 32).

To speak about aging is to enter an area in which some basic anxieties and aspirations about human life are expressed. Castiglione's Book of

46 See Floyd Gray, Montaigne bilingue. Le latin des "Essais" (Paris: Champion, 1991), pp. 99-118. 
the Courtier forcefully reminds us that every society creates the old men it deserves. Montaigne's "On some verses of Virgil," on the other hand, stresses the complexity of personal experience, and suggests ways of aging gracefully in a manner that neither imprisons us at the level of the particular nor eradicates the specificity of this process by lapsing into abstract generalities.

"It is a myth that old age is typically a time of passivity," an older English woman observed in the 1980 s. "The truth is closer to the opposite; since later life is a time of sharp change, it demands a special responsiveness and imaginative adaptability." 47 Four centuries before her, Montaigne had already capitalized on a similar perspective. "Since it is the privilege of the mind to rescue itself from old age, I advise mine to do so as strongly as I can," he noted in "Some verses of Virgil." "Let it grow green, let it flourish meanwhile, if it can, like mistletoe on a dead tree" (III, 5, p. 844/p. 777).

\section{Pasquier}

"Nobody can be physically young and old at the same time," Saint Augustine contends. "Yet, one can be both intellectually; and have a youngfast-and old-wise-mind." 48 His remark applies perfectly not only to Montaigne but also to one of the essayist's friends and admirers: Etienne Pasquier. For our purposes, Pasquier's Pastorale du vieillard amoureux (Pastoral of the Old Man in Love) and Jeus Poétiques (Poetic Games) are especially interesting. ${ }^{49}$ His contemporary, Scévole de Sainte-Marthe, praised Pasquier's sociable manners and witty mind ${ }^{50}$ — two qualities well appreciated in his social and intellectual circle. In contrast to Ronsard (whom he knew and whose works he admired), Pasquier seemed to have been blessed with a healthy old age until his death at age eighty-six. Like

47 Quoted in Pat Thane, History of Old Age in English History (Oxford: Oxford University Press, 2000), p. 245.

48 Saint Augustine, Retractationum libri II, ed. A. Mutzenbecher (Turnhout: Brepols, 1984), vol. 1, chapter 26, p. 8o. My translation.

49 Etienne Pasquier, Oeuvres complètes, 2 vols. (Geneva: Slatkine Reprints, 1971). References to La Pastorale du vieillard amoureux are to this edition and are incorporated into the text. Les Jeus Poétiques, ed. Jean-Pierre Dupouy (Paris: Champion, 2001). References to Les Jeus Poétiques are to this edition and are incorporated into the text. All translations of both works are my own.

50 Scévole de Sainte-Marthe, Opera, tum poetica, tum ea quae soluta oratione scripsit. Scaevolae Sammarthani Lucubrationum, pars altera, qua continentur Gallorum doctrinae illustrium, qui nostra patrumque memoria floruerunt, elogia (Paris: Durand, 1616), pp. 277-78. 
Montaigne, in his Pastorale du vieillard amoureux Pasquier refused binary stereotypes of young-versus-old, while providing us with an inside view of the pastimes of his worldly coterie.

A brief account of the events surrounding the composition of this work is called for. Soon after her marriage with the influential Albert de Gondi, Claude-Catherine de Clermont, the Duchess of Retz, ${ }^{51}$ became the center of an intellectual court. That she was esteemed by her contemporaries is shown in the praise she received and the numerous works dedicated to her. Well before the Marquise de Rambouillet, she opened her salon to humanists, politicians, courtiers, and writers who came to share their hostess's passion for conviviality and conversation. The writers Philippe Desportes, Pontus de Tyard, Jean-Antoine de Baïf, and Amadis Jamyn were among the duchess's regular guests.

In a letter to his friend Pierre Airault dated December 1591, Etienne Pasquier writes that some three weeks earlier he had been invited to a dinner party at the home of the duchess. He describes the range and breadth of conversation, from personal concerns to general comments on justice and work. The guests spoke freely about the social and political upheavals of the day which were on everyone's mind since France was in the midst of a civil war. After such serious matters, the discussion turned to love, a topic well-suited for a festive evening, leaving plenty of room for wordplay and wit. Pasquier was well equipped to contribute to this exchange since his two dialogues entitled the Monophile address this very question, but he was immediately interrupted by the duchess, who wanted to stir things up by declaring that it was inappropriate for an old man to discourse on love. The word she used was "bon homme," which, according to Antoine Furetière's Dictionnaire universel (1691) meant a "harmless old man." ${ }^{52}$ Quickly catching on to the duchess's game, Pasquier, then sixtytwo years old, reports to Airault that he pretended to see her comment as a grave insult, an "eighth mortal sin." The offensive word "bon homme," he said ironically, reduced him to "a piece of garbage" ("une pièce de rebut," II, pp. 897-98).

The incident did not generate any special comment but gave rise to a sparkling war of wits. Retz's guests turned their attention to a questione d'amore: "who can better speak of love, a young man or an old

51 Catherine de Clermont (1543-1603), formerly Maréchale of Retz, became Duchess in 1582 .

52 Antoine Furetière, Dictionnaire universel (Rotterdam: Arnout and Reinier Leers, 169o), p. 98 . 
one?" Debates, to be sure, often allow successive speakers to contradict one other, the assumption being that dialogues between opposed viewpoints are a way to the truth. Here, however, ingenious improvisations were more important than finding the eventual right answer. Not unlike actors from the commedia dell'arte improvising on set patterns, members of the drawing-room set moved from spoken to written performances, taking up personae and engaging in discussions or texts on familiar issues. ${ }^{53}$ Since the Ancients, the moment of mealtime stands above all other group pleasures; dialogue and conviviality give rise to playfulness. For Georg Simmel, "in purely sociable conversation the content is merely the indispensable carrier of the stimulation, which the lively exchange of talk as such unfolds... that something is said and accepted is not an end in itself but a mere means to maintain the liveliness of the mutual understanding, the common consciousness of the group." 54 The debate on love gave the duchess's guests a great opportunity for such interaction; it stimulated jokes and puns, delightful to an intellectual coterie bound together by a common literary culture. Disagreement and midly provocative propos lent spice to the exchanges; inviting objections and debate was but a way of reinforcing consensus and agreement among the guests.

Inspired by the incident of this soirée, the next day Pasquier wrote a Pastorale du vieillard amoureux, dedicated to the Duchess of Retz. In his letter to the duchess, he offered a challenge to boys without experience in love, and claimed that his gray beard gave him special privileges to dispense kisses in a manner that young men would never attempt. After being circulated in manuscript, the Pastorale du vieillard amoureux appeared in print with a preface consisting of the letter to Airault and the dedication to the Duchess of Retz, followed by a short poem. In addition, Pasquier's letter to his friend the lawyer Pierre Pithou was appended to the piece and served as a general comment on the incident. Like the dinner conversation from which it originated, Pasquier's work refers to a number of precepts required in an exchange between people of refinement.

It comes as no surprise that old age should be the focus of a social game about words. Pasquier was far from being the only graybeard in Catherine

53 Julie Campbell, Literary Circles and Gender in Early Modern Europe. A Cross-Cultural Approach (Burlington, VT: Ashgate, 2006), p. 74, stresses the continuity between oral and written communication: a conversation inspires Pasquier's written dialogue, this dialogue circulates in manuscript and is ultimately recorded in print.

54 Georg Simmel, “The Sociology of Sociability," American Journal of Sociology 55 (1949), pp. 259-6o. 
de Clermont's literary circle; Pontus de Tyard, a regular guest of the Retz salon, was seventy years old in 1591. The duchess herself was forty-eight, but Pasquier, diplomatically, had no desire to raise this issue. Conceived as a form of after-dinner entertainement, his Pastorale du vieillard amoureux capitalizes on a confraternity of speech, manners, thoughts, and interaction to display Pasquier's rhetorical skills and esprit d'à propos. An exercise in tact and finesse, an elegant demonstration of the refined ease of an author who can turn casual conversation into art, the Pastorale du vieillard amoureux presents alternatively positive and negative views on love in old age-just like the debate from which it sprang. As a brilliant lawyer, Pasquier was well equipped to act as the old man's attorney, prosecutor and judge. At the opening of the pastoral, the poet introduces the characters of the dialogue: the shepherd Tenot, the shepherdess Catin, and the god Pan. Old Tenot is in love with young Catin, and tries to convince her of the advantages of an older lover. An older and weaker body, he contends, imposes measure on sensual pleasures, and increases man's wisdom. Personally, Tenot does not feel his age and maintains that chronological age explains nothing, because it is an arbitrary index. Since aging, as applied to human existence, implies a multiplicity of perspectives (biological, medical, psychological, etc.), Tenot criticizes abstract representations of old age as a distinct stage of life with a common set of fixed features; he argues that metamorphosis is the essence of life. Commenting on the natural cycles of growth, maturation, and decay, he encourages Catin to enjoy every moment of her ephemeral youth, for nothing is permanent in this inconstant world, and death can come at any age. When it comes to love, Tenot is quick to boast of his age: as an older lover, he is discreet and faithful; moreover, his conversation is much livelier than that of a young man. His understanding of the nature of passion is a counterpoint to youth's foolish sexual impulse.

Catin then replies from a youthful perspective and points out old age's sour aspects. She criticizes Tenot for talking too much about love without acting. She dreams of a handsome young man who would love her night and day. There is a season for everything, she concludes, and Tenot should behave according to his age; consequently, she sends him back to his glass of wine and his beer, which are more suitable to his condition than love games. Each of the shepherds' speeches has exactly the same number of lines, thereby emphasizing the passing of time. Finally the great god Pan steps forward to reconcile the two shepherds, and advocates a partnership between old age and youth. The ideal is based on balance: Tenot and Catin are both right, Pan contends, in fact, they need one another. From 
the time of the Ancients, Pan was a familiar character of the pastoral landscape; his well-known sexual power eliminated any possible remark on Tenot's eventual impotence. When it comes to love, Pan maintains, age discrimination is a false problem since passion is similar to fire: the most enjoyable and intense flame comes from "burning a mixture of branches at once tender and old" (II, p. 9o6). The dialogue ends with alternate songs by the two lovers whose laughter chases away the gossipers. The final song celebrates the couple's happiness, sealed with a kiss.

Pasquier did not expect his audience to believe old Tenot and young Catin's love story. "I want to make it clear that I am not serious," he wrote to Airault (II, pp. 899-900). In his letter to the lawyer Pierre Pithou dated a month after the Retz dinner, he again stressed the ludic tone of his Pastorale du vieillard amoureux:

Puisque la vieillesse apporte mille incommoditez de corps et d'esprit quant et soy, je me veux chatoüiller pour rire, malgré la malice du temps, et de mon aage, et en ce faisant, bannir le chagrin au moins mal qu'il me sera possible, et me resjoüyr sans pecher. A la charge que si je desplais à quelques-uns, je veux qu'ils sçachent qu'aussi me desplaisent-ils, et si voulez que je passe plus outre, leur desplaisir est mon plaisir." (II, pp. 911-12).

Since old age brings a thousand inconveniences to the body and the mind, I want to tickle myself and laugh despite the evils of time and old age, thereby chasing sadness in the least possible harmful way, and rejoicing sinlessly. Now if I displease a few, I want them to know that they displease me too, and if you want me to go further, their displeasure is my pleasure. (II, pp. 911-12)

Social games of refined and witty expressions of desire were among the favorite pastimes of the French literary circles of the end of the sixteenth century, and jokes on intergenerational love were not exceptional. In 1579, Henri III pretended to fall in love with the old Duchess of Uzès and initiated with her a playful exchange of amorous verses that circulated widely among members of the court. ${ }^{55}$ In a similar way, the Duchess of Retz's Album de poésies - a collection of verses collectively and anonymously written by Catherine de Clermont's guests - contains poems praising the superiority of aging lovers over young and inexperienced ones. ${ }^{56}$ Pasquier's pastoral obviously has the light and witty tone of such exchanges, which

\footnotetext{
55 See Jacqueline Boucher, Société et Mentalités autour de Henri III (Paris: Champion, 2007), pp. 728-29.

56 See Catherine de Clermont, Album de poésies (Manuscrit français 25455 de la BNF), ed. Colette H. Winn and François Rouget (Paris: Champion, 2004), p. 75.
} 
made the reputation of the Retz salon. One may even think that Catin and Tenot's conversations alluded to and reshaped a great range of what was said at the banquet. If so, the different meanings and connotations imposed on the guests' exchanges would have been easily identified by anyone who attended the event.

More importantly, Pasquier's work playfully challenged powerful stereotypes of love in old age. On this question, books of manners such as the widely read Libro del Cortegiano set the tone in sixteenth-century French courtly and aristocratic circles. Six years prior to Retz's dinner party, Gabriel Chappuis's new French translation of Castiglione's dialogue was published by the Parisian librarian and printer Abel L'Angelier, with whom Pasquier collaborated. It was, of course, impossible to assimilate Pasquier to the old man who, in Fregoso's stern words in the Cortegiano, makes a fool of himself in others' eyes by sending love letters and chasing young girls (II, pp. 77-78). In Pasquier's work, love is the pretext for witty and friendly exchanges that echoed the dinner guests'gentle way of teasing one another at the banquet. The pastoral's playful rhetoric of praise, blame, and reconciliation follows the model of Poggio Bracciolini's poem "Should an Old Man Marry?" - a paradoxical praise of the marriage of a fifty-six-year-old man to an eighteen-year-old girl. ${ }^{57}$ Yet while following such rhetorical tradition, Pasquier's dialogue does not challenge social decorum and convenances; from the start, the aging author carefully dissociates himself from old Tenot. In a short poem concluding his letter of dedication to the Duchess of Retz, he wrote:

...ne pensez pas pourtant

Qu'un jeune object m'aille ainsi tourmentant,

Comme j'en fay, par mes vers contenance:

Je ne vy point en cest heur malheureux. (II, p. 901)

Don't think however that a young object is tormenting me like this, as I state in my verse: I don't live in this unhappy state.

Likewise, the pastoral's dedication to Retz eliminates any personal reference to Pasquier and vaguely alludes to a fictitious friend as the target of the offensive word "bon homme" uttered by the duchess. The idea of substituting an anonymous old man for Pasquier himself was an effective way of whetting the curiosity of the pastoral's potential audience, and

57 Gian Francesco Bracciolini, Un Vieillard doit-il se marier? ed. and transl. Alcide Bonneau (Paris: Liseux, 1877). This work was familiar to Pasquier's literary circle and inspired Pierre de Ronsard's first sonnet of the second book of the Sonnets pour Hélène. 
renewing the discussion that took place at the dinner party. The persons who attended the banquet would, in all likelihood, have been eager to reveal to other members of their coterie the real identity of the victim, along with the details of the conversation that took place that evening. If table conversation is the mode of production, conception, and reception of Pasquier's work, gossip serves as its discursive model. I do not mean to imply that the pastoral is just a form of gossip, but that its self-referential apparatus leads us to think about what it has in common with gossip. Like an oral story, it passes by word of mouth: Pasquier tells the little story to Airault in an introductory letter; his letter of dedication to the Duchess of Retz mentions a fictitious old friend who allegedly relates his misfortune to Pasquier who, in turn, recounts his story in his pastoral poem; Pasquier then gives further details in a letter to Pierre Pithou. The spreading of the news shows the network mode of "gossip" even if what is said is communicated in a way that is distinct from gossip's more typical self-referential techniques ("I shouldn't tell you this, but...").

Gossip is a powerful way for social groups to constitute themselves, to maintain cohesion and to reinforce convivial relations. One does not gossip just to anyone: the inclusion of some in the circle of gossipers to the exclusion of others serves to identify a group that has common interests or concerns. The circulation of information within the network constituted by the Retz coterie also serves to keep open, phatically, channels of friendly communication dear to its members. Gossip frequently functions to identify a scandal, serving the circle's need to explore its system of values: what constitutes "scandal" for a given group is an indicator of how the group keeps a check on behavior it considers illegitimate, or unusual, and on things worth discussing. In a sense, gossip reveals what one always "knew" yet never realized until it was articulated. ${ }^{58}$ Thus old age and the physical decline that goes with it need not marginalize someone socially, but can represent the most creative and imaginative period of a life, especially when it is a question of orchestrating the pleasures and pastimes of a learned and worldly circle.

The story of old Tenot in love with young Catin illustrates how a man who looks old in the eyes of another can be the most youthful and convivial of guests. In this respect, Pasquier's pastoral is an ironic response to negative stereotypes of the old man as unattractive, impaired, and

58 See Ross Chambers, "Gossip and the Novel: Knowing Narrative and Narrative Knowing in La Fayette and Proust," Australian Journal of French Studies 23, 2 (1986), pp. 212-32. 
socially dysfunctional, as depicted by the youthful Fregoso in the second book of Castiglione's Cortegiano (II, p. 78). Examples of such negative commonplaces already appear in Aristotle's Rhetoric (II, 12-14). By gracefully adapting to a process whose effects are beyond his control-growing old-Pasquier stresses the value of his age without being pretentious or offensive. Such an ideal (drawn from Cicero's notion of urbanitas, with its emphasis on politeness, grace, and elegance in social behavior) is a key aspect of the social identity of the cultural elite gathered in French salons toward the end of the sixteenth century. As a good guest, Pasquier is at pains to please his hostess and her lively circle of learned friends, for nothing makes a feast more jovial than laughter and trust. The genre of the pastoral is suggestive in this respect: to fall back on a conventional feature of Arcadia, the sum of young Catin's and old Tenot's respective ages becomes the Golden Age. Youth and age come together: pleasure and wisdom become conjoined, love and contemplation are united.

Pasquier wrote in a letter to his friend Pierre Pithou a few weeks after Retz's dinner party: "Did you ever see anything as funny as this? That I, in the winter of my age, in the midst of France's upheavals, gave myself a new career, and amused myself writing a love pastoral?" (II, pp. 911-12).

The dedication of the pastoral to the Duchess of Retz was a way for Pasquier to remain a key player at table conversations despite, and ultimately because of the physiological changes taking place in his body. For Linda Hutcheon, "irony is a relational strategy in the sense that it operates not only between meaning (said, unsaid) but between people (ironists, interpreters, targets). ${ }^{59}$ We do not have a record of the duchess's reaction to Pasquier's Pastorale du vieillard amoureux, but she had every reason to enjoy its wit. A refined and learned lady widely admired for her erudition and literary taste, the duchess expected a work to be sound, entertaining, and elegant. The pastoral certainly struck the right note. In addition, Retz was part of the theater-loving circles of Catherine de Medici, Marguerite de Valois, Henri III and Henri IV, who were so taken by Italian actors that they attracted some of the best ones to France and frequently commissioned their performances. As an intimate friend of the royal family, the Duchess of Retz took part in court entertainments, and performed in masques; most famously in the Ballet comique de la Royne. ${ }^{60}$ Pasquier's work capitalizes on Retz's infatuation with elements of the pastoral

59 Linda Hutcheon, The Theory and Politics of Irony (London: Routledge, 1994), p. $5^{8 .}$

60 Julie Campbell, Literary Circles and Gender in Early Modern Europe, pp. 77-81. 
tradition, especially with Sannazaro's Arcadia, a work which, incidentally, addresses the issue of old men in love. The duchess's aristocratic female friends were often referred to as nymphs, muses, and goddesses from classical antiquity; Catherine de Clermont was Dictynne (a nymph from Crete said to be an attendant to Diana), and her salon was called le salon vert. Moreover, from Clément Marot to Pierre de Ronsard and onward, Tenot and Catin were conventional names for French pastorals, but they also transparently alluded to the first names of Etienne Pasquier and Catherine de Clermont. In this respect, the pastoral playfully subscribed to the claim that "all the world is a stage": "Look at this old man entering the stage to play his character" (II, pp. 899-90o), Pasquier wrote in his letter of dedication to Retz.

The pastoral genre has often been viewed as offering a nostalgic representation of lost youth, but a significant proportion of them elaborate on the opposite perspective. Indeed, since Virgil's first Eclogue, the bucolic world is the ideal home of old age. In Virgil's work, old Tityrus "reclining at ease on a bench beneath the cover of a tree" enjoys the "god-ordained" otium or peaceful leisure intrinsic to the pastoral ideal. "Fortunate senex" declares the unhappy Meliboeus who is forced to leave his land, whereas Tityrus is permitted to stay. ${ }^{61}$ For centuries, Virgil's first Eclogue was required reading for any beginning student of Latin. Pasquier's reference to this familiar work shows his esprit d'à propos since Tenot's love for Catin echoes Tityrus's love for young Amarillys. Pastorals were originally the improvised songs of Greek shepherds; in the same spirit, the Pastorale $d u$ vieillard amoureux is eloquence in the making, and its readers were improvisers who would judge the work on the spontaneity of its effects (a spontaneity artificially recreated in writing), on its ingenious use of words, and on the good manners of its author. As Pasquier observed in his letter to Airault, the dinner guests who witnessed the "bon homme" incident were all "beaux esprits" who excelled in the dissection of feelings, feigned passions, and emotions. Pasquier was a master at such improvisations, if we are to judge by the literary competitions on La Puce and $L a$ Main that he organized in Poitiers and in Troyes, respectively. In both cases, a daily life event (a flea that Pasquier claimed to have seen on Catherine des Roches's breast, the absence of hands in a painting of Pasquier as a lawyer) becomes the pretext for light pieces aiming at reinforcing the

${ }^{61}$ Virgil, "First Eclogue", in Eclogues, ed. and trans. R. Coleman. (Cambridge: Cambridge University Press, 1977), ll. 1, 6,46. 
conviviality of a closely-knit literary coterie. Such works focused mostly on style since they offered the poet an opportunity to accumulate ingenious turns of phrase and paradoxes. The slighter the content, the higher the level of wit, grace, and subtlety of the expression. ${ }^{62}$

Similarly, the debate on love that took place at Retz's dinner party called for equal contributions from the guests. Games are a powerful means of social integration; they require the players' involvement and rely on a mutually congratulatory process. Pasquier could admire his own private wit, as he states in a short poem at the end of the dedication of the pastoral: "I am in love only with myself, and don't think of another misfortune in my heart" ("Je suis de moy seulement amoureux, Et autre mal en mon cœur je ne pense" II, p. 9o1). By addressing the questione d'amore at the dinner party debate in terms of experience, Pasquier did more than show an old man's superiority in speaking of love; he pointed out how important it is for young people to draw on their elders' rhetorical skills and experience. Hence his pastoral complied with the three goals of rhetoric as defined by Cicero: pleasing, moving, teaching.

These imperatives are embodied in an apparently artless dialogue that reflects the wit of the Retz salon. An ideal guest was required to talk about everything and nothing, to be in turn serious and frivolous, profound and amusing. Yet a meaningful experience emerges from the chance events that produce it. The guests' infatuation with Arcadia, or with similar utopian images, was not merely an escape from the Religious Wars and social conflicts of the day. Even if Pasquier's Pastorale du vieillard amoureux was written in response to a trivial incident at a dinner party, it conveyed a wider plea for tolerance, peace, and harmony. Interestingly, the Pastorale du vieillard amoureux depicts old Tenot as dispossessed. Everyone knew that in Virgil's first Eclogue, Meliboeus's exile was the consequence of the Roman civil wars. ${ }^{63}$ Pasquier's own misfortunes at the time of the Pastorale were not unrelated to that of Meliboeus: in 1588, when he left Paris to attend the Etats Généraux at Blois, he sojourned in Tours where Henri III had established the Parlement and the Chambre des Comptes. "I have lost all my wealth because of the Ligue" (II, pp. 897-98), Pasquier writes to Airault in the letter prefacing his pastoral. When he returned to Paris in 1594, his house at the Quai de la Tournelle had been sacked.

62 Gisèle Mathieu-Castellani, Les Thèmes amoureux dans la poésie française (1570-160o) (Paris: Klincksieck, 1975), pp. 216-18.

63 Meliboeus is the tenant and not the owner of his land; he is in exile because his landlord's land has been given by Augustus to a veteran. 
Four years earlier, in May 1590, one of his sons, François-René, was killed at the siege of Meung-sur-Loire. Pasquier's wife, Françoise Belin, who had been jailed by the Parisian ligueurs, died the following October, soon after her release. ${ }^{64}$ Despite the upheavals of these wars, so lucidly described in Pasquier's letters, the Pastorale du vieillard amoureux celebrates the pleasure of storytelling. As the author ironically observes in his letter to Pierre Pithou, he lost everything during these wars except his mind (II, pp. 899-900). No wonder he appended this letter to his pastoral: it was a way of stressing the therapeutic function of social games and entertainments at a time of political instability and despair.

Interestingly, Catherine de Clermont was a member of the Académie du Palais established by Henri III. Like the Académie de musique et de poésie founded by Jean-Antoine de Baif, this institution capitalized on the regulation of social and artistic exchanges to promote France's unity of language, culture, and ethical values, and ultimately played a role in restoring peace in the kingdom. In a lighter vein, the pastimes of the Duchess of Retz's circle and Pasquier's pastoral complied with these goals: by stressing the values of friendship, conviviality, and leisure, they encouraged social harmony through games, music, and poetry. Debates, dialogues, speechmaking and speech evaluation were at the center of the two Académies' meetings, offering their members practical training for political negotiation. Such ideals, however, reflected the values and interests of their limited and select audience: despite their collaborative spirit, the Académies reinforced the gap between a small intellectual French elite and the rest of the kingdom. In this respect, Pasquier's Pastorale du vieillard amoureux participated in the creation of a convivial and tolerant French aristocracy of letters, epitomized by the banquet from which his work originated. "Age is an issue of mind over matter. If you don't mind, it doesn't matter," Mark Twain wryly observed. ${ }^{65}$ Several centuries before him, Pasquier's Pastorale du Vieillard Amoureux had already offered a witty demonstration of this.

In his Jeus Poétiques (1610), the eighty-one-year-old Pasquier had an even more ambitious goal. He represented his éducation sentimentale from youth to old age, ironically calling into question the division of life into ages with a common set of fixed features, and challenging the reader

64 Paul Bouteiller, Recherches sur la vie et la carrière d'Etienne Pasquier, historien et humaniste du XVIe siècle, (Paris: Editions I.S.I., 1989), pp. 33-48.

65 See http://beliefnet.com/Holistic-Living/index.aspx. Accessed March 14, 2013. 
to view him as an old man (p. 106). Les Jeus Poétiques contrasts the poet's own sentimental life with a series of commonplaces that reflect conventional views of the stages of life, thereby stressing that such set "stages" are only meaningful in terms of individual responses to them. The collection is a montage, since the octogenarian author recycled some of his earlier poems. Revisions had been made, new poems were added, while others were deleted; a coherent narrative emerged delineating Pasquier's own stages of the life cycle.

More importantly, Les Jeus Poétiques blurs the distinction between the practice of a literary style, and the shaping of one's identity over time. The collection is, in many ways, an anthology of French love poetry's major rhetorical trends in the second half of the sixteenth century, and playfully reviews the amorous behaviors that inspired Pasquier's own poetry during his long career. The author knew that he was dipping into material that any member of his literary and social circle would recognize, and therefore would enjoy understanding the allusions. Stereotypes of old people describe them as absorbed in contemplating their past and not interested in the present, but such was not Pasquier's case since he adapted his verses (some of which had been published as early as 1555) to the audience of 1610, when Les Jeus Poétiques was published.

The work contains five sections, but to examine them separately is to lose the sense of the complex interactions between the "self" and literature that is at the heart of this work. Pasquier's collection engages its readers with an experience of the instability of the literary canon as a product of shifting tastes. Moreover, it playfully shows that, as Foucault notes, there is no such thing as an a priori theory of the subject independent of specific forms of knowledge and a certain number of practices. ${ }^{66}$

What marks Les Jeus Poétiques is the imprint of Pierre de Ronsard on Pasquier's successive self-definitions, as both poet and lover. As the most versatile poet of his time, Ronsard had excelled in every form and possible expression of desire, tirelessly drawing his inspiration from Italian, Greek, and Latin sources to enrich the French literary repertoire. Pasquier's acknowledgment of Ronsard's lasting influence on his own career was a way to share in the glory of this famed poet. The old writer could proudly show his 1610 audience that he had been an active member of the famous Pléiade which, under Ronsard's leadership, gave France a renewed cultural prestige. This claim reappears in book 7 , chapter 6 of the Recherches

66 See Foucault, "The Ethic of Care for the Self as a Practice of Freedom", p. 10. 
de la France, a work that Pasquier was writing at the same time as the Jeus Poétiques (Oeuvres, I, p. 701). Likewise, in a letter dating between 1589 and 1605 , Pasquier wrote to his friend, the poet Pontus de Tyard: "Si je ne m'abuse, vous et moy restons presque seuls en cette France de cette belle brigade, que produisit le regne du Roy Henry II" (Oeuvres, II, p. 462). ("If I am not mistaken, you and I are about the only ones left in France of this beautiful brigade produced by the reign of King Henri II"). ${ }^{67}$ A medal of Pasquier's was engraved in 1605 (five years before the publication of Les Jeus Poétiques) and represented him as the Gallic Hercules dragging people by his tongue. The image referred to Pasquier's rhetorical gift as a brilliant lawyer, but any learned contemporary would have caught the allusion to Henri II's royal entry into Paris in 1548. The evocation of the Gallic Hercules had been part of this ceremony. A mention of the god of French eloquence famously reappeared a year later, at the end of Du Bellay's La Deffence et illustration de la langue françoyse (1549), the "manifesto" of the future Pléiade. 68

When preparing his collection, Pasquier surely had in mind the example of the aged Ronsard gathering his earlier publications in successive editions of his complete works. Ronsard had conceived his Oeuvres as an immortal poetic monument; likewise, Pasquier's Les Jeus Poétiques was the product of a theatrical culture. Both authors carefully revised their previous texts and organized them in meaningful ways. By dialoguing with their own literary productions, they capitalized on their capacities to make and remake themselves, to resist the social constraints and imperatives imposed upon old age.

In the address to the reader prefacing his collection, Pasquier claims to present his own love affairs, but in reality, each section of Les Jeus Poétiques creates the effect of a collective discourse on love by elaborating on impersonal, stereotyped amorous behaviors at different ages of life. The first section, "Loyaulté," presents the poet lover as a "young man in the age of innocence" (p. 105). Since this part contains the greatest number of the author's earliest verses, it is not surprising to find conventional Petrarchan conceits and imagery. The lover finds himself a prisoner of a beautiful and cruel lady, after love's fatal glance comes the standard description of the physical and moral perfections of the beloved. The

67 The Brigade was the first "incarnation" of the Pléiade.

68 Joachim Du Bellay, La Deffence et Illustration de la langue françoyse, ed. Jean-Charles Monferran (Geneva: Droz, 2001), p. 45. 
young lover worships his lady, but his efforts to seduce her remain vain; his obsessive passion becomes a source of frustration and torture. All the Petrarchan paradoxes so fashionable in the love poetry of the 1550 (the icy fire, the darkness of light, and so on) are present to express his contradictory feelings. Half a century later, Pasquier was fully aware that many aspects of this rhetoric seemed outdated. His Jeus Poétiques reassessed the tone of his youthful verses, stressing the ridiculous figure cut by the young poet lover of "Loyaulté." These verses, the old poet now declares to the reader, were written with tongue in cheek, and should be read accordingly: "En un mot je laisse au grand Petrarque pour closture de ses amours, un long repentir" (p. 106). ("In a word, I leave to the great Petrarch, as closure to his loves, a long repentance.") He also mocks the poet Tasso for going mad over his unrequited love for the Princess of Ferrara (p. 106).

Already in 1553 the fashion had begun to turn away from the Petrarchan representation of the faithful lover. Ronsard sarcastically accused Petrarch of playing the transfixed lover (I, pp. 168-69). Intent as ever on inscribing his own career into the poetic record of his time, Pasquier reacted in a similar way in 1555 and questioned the sincerity of Petrarch's passion, as well as that of his numerous imitators (Oeuvres I, p. 145). In "Liberté," the second section of Les Jeus Poétiques, he adopts the posture of the inconstant lover championed by Ronsard. Some poems in "Liberté" also mention Du Bellay and Tyard (Sonnet 13), members of the Pléiade. This section incorporates poems published in 1555 and 1578 , and is a compendium of commonplaces on youthful lovers who turn women into objects that they long to possess.

Despite this blending of lyrical voices, Les Jeus Poétiques is not the work of a dilatory and servile imitator, but rather of a lawyer well equipped to give rhetoric a central place in the creation of his "roman d'amour." Each section of the collection contains the seeds of the next ones and demonstrates Pasquier's versatility in his self-casting as a lover. "Loyauté" focuses on the young and inexperienced lover's obsessive passion for a single woman; "Liberté," in contrast, depicts a more mature protagonist who is determined to enjoy every opportunity for love affairs because nothing is permanent. Whereas "Loyauté" elaborates on images of entrapment in the labyrinth of love, "Liberté" focuses on instability as a general principle governing human behavior, and the world as a whole. The third section, "Ambition," complements Pasquier's catalog of amorous behaviors by playfully adding a new character to the repertoire of French love poetry. The protagonist, now in middle age and married, has adopted the identity of a successful lawyer. He climbs the social ladder and concentrates on a 
professional career which leads him away from love. His lust for money, glory, and fame echo many of Ronsard's poetic concerns, but these motives now strike an ironic note since they appear as part of adulthood's bourgeois pragmatism. The section concludes with an elegy spelling out a husband's and a wife's respective duties for living peacefully, and expresses concern for the couple's future children (pp. 314-16).

As he reaches old age, the protagonist falls in love again. The fourth section on "La Vieillesse Amoureuse" ("Old Age in Love") challenges the idea that individuals do not revert to earlier stages. Wounded by Cupid's arrow, the aged lover shows every sign of the youthful passion seen in "Loyauté." The old man in love is a comic figure per se, much present in the French comedy of the period, and Pasquier's own Pastorale du Vieillard Amoureux was a witty contribution to this genre. Yet, to limit the interest of "La Vieillesse Amoureuse" to its comic potential would be to give little credit to its creative energy. Like Ronsard's Sonnets pour Hélène, this section ironically revisits the powerful Petrarchan model of love poetry. Both Ronsard and Pasquier find new resonances from their earlier Petrarchan poems. In Ronsard's poems to Hélène, for instance, the lover alleges that his beloved's gaze rejuvenates him, and playfully questions the benefits of this change:

Quand tu as reverdy mon escorce ridée

De ta jeune vertu, ainsi que fit Medée,

Par herbes et par jus le pere de Jason,

Je n'ay contre ton charme opposé ma defense:

Toutefois je me deuls de r'entrer en enfance,

Pour perdre tant de fois l'esprit et la raison (II, S 40, ll. 9-14, p. 399)

When you restored youth to my wrinkled bark with your youthful virtue, just as Medea did for Jason's father with herbs and juices, I did not defend myself against your charm: and yet I am distressed to reenter childhood, losing my wit and my reason so many times. ${ }^{69}$

In a similar way, Pasquier reinforces the fated nature of the aged lover in "La Vieillesse Amoureuse" by parodying the first section of his Jeus Poétiques. Both sonnets I and II, for instance, echo the young and inexperienced lover's innamorento in "Loyauté." Ardent in his desire, heedless of the consequences of his passion, the aged lover shows no sign of the stereotypical prudence and wisdom of old age. His reason fails to resist being attracted to sensual pleasure. Circling back to second youth, he puts

69 My translation. 
his beloved on a pedestal, but is lucid enough to appreciate the absurdity of his passion. Absurd as his love may be, it is a process of self-discovery, a whole reassessment of the aged lover's sense of identity.

Other aspects of Pasquier's story of love in old age ironically echo Petrarch's passion for Laura in his Canzoniere (to which Ronsard also referred in his Sonnets pour Hélène). Like Petrarch's beloved, the lady falls ill, then ages faster than her older lover, and becomes like a "repulsive carcass" (S 15). A lawyer by profession, Pasquier adds a smiling judiciary touch to this satirical portrait: on her deathbed, the lady makes her will and donates her wealth to the old poet lover $\left(S_{17}\right)$. The section ends with a game about words: two songs present arguments for and against a love relationship between an old man and a young woman. The aged lover concludes by saying that he does not tell the truth either when he claims to love the young lady or when he pretends not to love her. His statement immediately prompts a response from her: she mocks his rhetorical subtleties and says that when it comes to love, no old man can be taken seriously (pp. 337-42).

Throughout the Jeus Poétiques, the self is a dynamic multiplicity of relatively autonomous "I" positions in an imagined landscape. The division of the collection into ages stresses the provisional and fragmentary nature of the individual subjects while also suggesting the dependence of the subject's identity on a web of social relations. Each "I" has a story to tell about its experiences from its own standpoint. By and large, the poems gathered in the two sections on old age had not been published previously; they were the work of an octogenarian author who had firsthand knowledge of this stage of life. In "La Vieillesse Rechignée" ("Grumpy Old Age"), the final section of the collection, Pasquier elaborates on yet another set of commonplaces on old age which Ronsard had explored before him. As he reaches the stage of decrepitude, the protagonist of Les Jeus Poétiques becomes disillusioned about love. He has become an unattractive, impaired, and socially dysfunctional person. Even worse, he appears as a narcissistic and selfish man who finds everything in the world displeasing, including himself, and longs for death to deliver him from his wretched life (p. 364).

Yet discouragement and despair are not the final words of this éducation sentimentale on life's stages. Instead, the octogenarian Pasquier ends his collection by playfully praising the pleasure of illusions, and his own wit:

De l'Amour je me mocque, et encores de moy,...

Et voiant que ce Tout n'est rien que vanité,

Bien vivre, et m'esjouir c'est ma Philosophie. (p. 370). 
I make fun of love and also of myself...

And seeing that everything is but vanity,

Living well and rejoicing is my Philosophy.

When confronted by the mutability of both human existence and rhetorical fashion, Pasquier offers neither resignation nor acceptance, but rather the ability to respond imaginatively to the passage of time, with a smile. Today's gerontologists observe that as we grow old, we have a greater capacity to appreciate the multiple levels of our stories, the multiple characters within them, the multiple selves that tell them, and the multiple interpretations of the events that make them up. And we also acquire a greater capacity to laugh at our lives in a detached yet affectionate manner. As Pasquier's dual representation of love in old age makes clear, multiple versions of a person's life can be woven around the same basic set of facts. ${ }^{70}$ At age eighty-one, Pasquier knew he was approaching the end of his life, but joyfully pretended to forget his age. Even for an octogenarian, there was the prospect of opening up a new chapter.

As he watched himself growing old, Pasquier learned to enjoy what he had without clinging to it. This, in turn, meant that he could not only increase his chances of experiencing joy but increase the chance that the joy he experienced would survive changes in a world where everything is short-lived and perishable. In George Bernard Shaw's words, "We don't stop playing because we grow old, we grow old because we stop playing."71 Play was the very sign of the wisdom he had acquired during his long life. Like Montaigne and Ronsard, he confronted age stereotypes but did not challenge social decorum and convenances. Throughout Les Jeus Poétiques, love is a poetic experience that is less about having certain ends in mind than about coming to terms with new beginnings.

If love is a game, poetry is another, more serious kind of play. Les Jeus Poétiques was conceived as a social entertainment for the learned guests of the French salons, but its playful tone did not prevent its author from dreaming of literary fame. No author is able to predict which one of his works will survive the ravages of time, Pasquier notes in his address to the reader; sometimes posterity gives a stamp of approval to a few lines that

70 Gary Kenyon, E. Bohlmeijer, and W. L. Randall, Storying Later life. Issues, investigations, and interventions in narrative gerontology (Oxford: Oxford University Press, 2011), pp. ix-x. See also Randall and McKim, Reading Our Lives. The Poetics of Growing old, pp. 161, 281, 217-21, 236, 240. Whether the "self" is behind these various masks, or among them, is beyond the scope of this study.

71 Cf. http://beliefnet.com/Holistic-Living/index.aspx. Accessed March 14, 2013. 
were written just for fun, while the text that its author most values may go unnoticed and sink into oblivion. He then adds: "Quel sera le hazard de mes Jeus Poétiques (ainsi me plaist-il les nommer) je ne m'en donne pas grande peine." (p. 105) ("What will be the fate of my Jeus Poétiques (as I like to call them), I don't really care"), One may, however, question the sincerity of this statement since in a letter to his friend Antoine Loisel he wrote: "et peut-estre adviendra-t-il que celles [mes oeuvres] dont je fais moins de compte seront les mieux recueillies" (Oeuvres II, p. 282) ("and maybe it will happen that those of my works I value the least will be best received." $)^{72}$

In reentering the social stage with a collection of love poetry at age eighty-one, Pasquier was aware of the gamble. He who had been ahead of his time as a member of the Pléiade in the 155 os now fell back upon the role of witness, passing his experiences on to new generations of poets. What he wanted to pass on to his successors were the arts of detachment and discernment. Both had poetic implications. What are the broader consequences of his acute and compassionate observation of human comedy? If we consider that our age is an integral part of our identity, we must also recognize that our age is also frequently in potential tension with our identity. We subjectively cling to an image of ourselves as unchangingly young. While our mind may support this phenomenological sense of coherence and continuity, our body's external appearance belies this image. ${ }^{73}$ Like Petrarch, Ronsard, and Montaigne, Pasquier used stereotyped and abstract accounts of the stages of life to promote a much more varied notion of love in old age as both a social and a literary process.

\section{Conclusion}

The self-portraits discussed in this chapter reveal something about the perception of old age in their respective writers' social groups. Despite their resistance to widespread stereotyped views on the winter of life, the dual portrait of the lustful old man and the chaste old man did not disappear. By the end of the sixteenth century, both representations still

72 This remark predated the publication of Les Jeus Poétiques, but Pasquier kept thinking of the enduring fame of the Decameron, a work that Giovanni Boccaccio did not consider his masterpiece (Oeuvres II, p. 282).

73 On this notion, see M. Featherstone and A. Wernick, Images of Aging: Cultural Representations of Later Life (London: Routledge, 1995); S. Biggs, "Choosing not to be old. Masks, bodies and identity management in later life," Ageing and Society 18 (2007), pp. 209-21. 
permeated every field of Renaissance arts, science, and letters. Among countless examples in literature, in his posthumous defense of old age De bono senectutis (1597), the cardinal Gabriele Paleotti links old age to serenity, while associating youth with sexual appetite. Likewise, in his Sage vieillard (1606), the French protestant Goulart praises the old man's traditional wisdom and reason, and equates love in old age to Christian caritas and preparation for the afterlife. In a less assertive way, Guicciardini notes that from his forties on, a man should remember that youth is under the sign of Venus, and that old age is associated with Saturn. These planets, he adds, are in opposition to each other ("l'una dall'altra molto contraria"). ${ }^{74}$

Stereotypes confirm the notion of a stable and universal life cycle with recognizable stages, but the representations described in this chapter confounded these abstract constructions. Aging ceased to be understandable in terms of any common or totalizing experience. It was no longer a fixed and homogeneous process, but rather a complex experience expressed in a variety of ways and viewed from different perspectives. The self-portrait of the writer as an elder in love gave Petrarch, Montaigne, Ronsard, and Pasquier the opportunity to choose a variation promoting their own uniqueness.

${ }^{74}$ Niccolo Guicciardini, L'Ore di ricreazione, ed. A.-M. Van Passen (Rome: Bulzoni, 1990), p. 283 . 